\title{
Development Of Anti Miskim Software To Reduce Misconception With Conceptual Change Text Strategy Students Of Class X In Chemical Bonding Material
}

\author{
Galuh Eka Wulandari, Sukarmin*, Rusly Hidayah \\ Surabaya State University \\ Surabaya, Indonesia \\ Sukarmin@unesa.ac.id
}

\begin{abstract}
This study aims to determine the feasibility of developing Anti Miskim software to reduce misconceptions of students of class $X$ in chemical bonding material. This type of research is a development research that develop Anti Miskim software on chemical bonding material and research design used is $R \& D$ research (Research and Development). Target of this research is student of class XI MIA SMA Negeri 1 Krembung. The instruments used are the review sheet, content validation sheet and construct, student response questionnaire, and student activity observation sheet. Software developed using PHP programming language. The results showed that (1) the validuty of Anti Miskim software on chemical bonding material obtained an average validation result of 0.775 , for content validation of 0.75 with high criterion and construct validation of 0.8 with very high criterion. (2) the practicality of Anti Miskim software on chemical bond material based on student response result supported by data of observation result of student activity get average result equal to $94.07 \%$ with very good criterion (3) Anti Miskim software effective in reducing student misconception as indicated by percentage the average shift of conception from misconception to know concept is $81.26 \%$.
\end{abstract}

Keywords-Anti Miskim Software, Misconception Reduction, Conceptual Change Text, Chemical Bonding.

\section{INTRODUCTION}

Chemistry is a branch of natural science that studies the structure of matter, the composition of matter, the nature and changes of matter and the energy that accompanies the material changes.

Chemistry subjects have characteristics: (1) most of the concepts are abstract, simple, tiered, and structured, (2) a science to solve problems and describe facts and events [1]. The common concepts of misconception in students are the concepts of matter, energy, acids and bases, atomic structures, molecules and chemical bonds, electrolyte and non-electronic solutions, chemical equilibrium, redox reactions, and chemical bond complex reactions [2].

Based on the results of pre-research in various schools the percentage of the average conception of students who experienced misconception in SMAN 4 Bangkalan as much as $24.76 \%$, in SMAN 12 Surabaya as much as $31.89 \%$, in SMAN 1 Krembung as much as $27.43 \%$. For MK1 (misconception 1) in SMAN 4 Bangkalan 9.52\%, in SMAN 12 Surabaya $15.14 \%$, in SMAN 1 Krembung $9,71 \%$. For MK2 (misconception 2) in SMAN 4 Bangkalan is $24,76 \%$, in SMAN 12 Surabaya $13,51 \%$, in SMAN 1 Krembung $17,14 \%$.

Misconceptions that occur in students must be eliminated and should be of particular concern to the teacher as well as the students themselves, because conception is very strong and relatively stable [3]. The consequences can be caused if misconceptions are not overcome that can disturb the next conception.

One attempt to reduce misconceptions is to use conceptual change text. The learning of conceptual change is described as part of a learning mechanism that requires students to change their concept of phenomena or principles either through restructuring or integrating new information into existing schemes [4].

Conceptual change has four stages, (1) showing student conceptions, (2) creating conceptual conflict, (3) equilibration process, (4) reconstructing student conceptions. The conceptual change model is based on important elements of prior knowledge and cognitive conflict [5]. The purpose given by such conflict situations is that students will be aware of their misconceptions and want to rebuild the original idea so as to motivate them in making the right understanding.

CCT is a teaching material that can help students change students' misconceptions with scientific concepts by revealing the student's early conceptions, reminiscent of the common form of common misconceptions, and then comparing with conceptions held by the conception of scientists through explanations and examples [6].

Several methods used to measure misconceptions that exist in the students are interviews and written tests. But the method takes a long time and is difficult to implement. To be able to reduce misconception on the students required an effective and fast media, because when using the manual will take a long time and tend not to be effective. For that we need a media that can reduce student's misconception quickly and effectively.

In the learning process, students must build a knowledge based on their own experience. The speed of students in building a knowledge and receiving new knowledge is different, with software that will be developed students can work in accordance with the ability of each and get optimal results. 
Other studies have also shown that previously developed software was able to detect chemical misconceptions on acidic and basic subjects [7]. Software can also be used as an instrument to measure the level of cognitive conflict in acidic base material [8].

\section{METHOD}

Type Research is a development study that develops anti-miskim software on chemical bonding material. This instrument was developed to reduce misconceptions in students for chemical bonding materials. This research uses R \& D research (Research and Development). The objective of this research is anti miskim software developed on Chemical Bond material which can be used to reduce student misconception for chemical bond material. This software was developed using PHP program. Here's the R \& $\mathrm{D}$ research design flow:

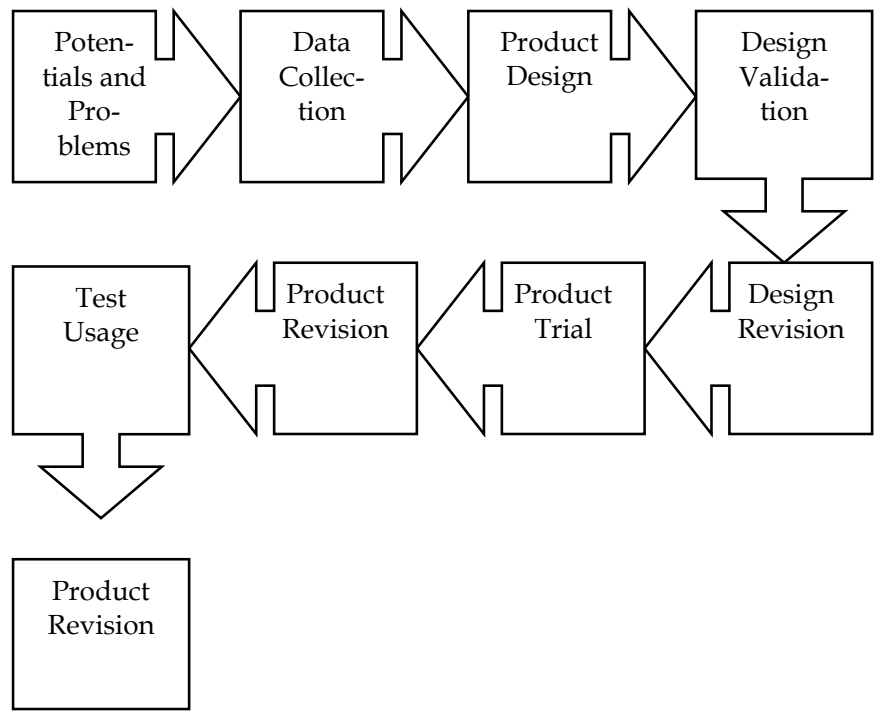

Fig. 1. Method Steps Research and Development (R\&D) [9]

The developed software consists of a pretest problem, with a three-tiered test for detecting misconceptions, conceptual change text (CCT), and a posttest problem on chemical bonding material. The classification of student answers with a three-tiered test is as follows:

TABLE I. GUIDELINES FOR STUDENT ANSWERING CLASSIFICATION[10]

\begin{tabular}{|c|c|c|c|}
\hline First tier & $\begin{array}{c}\text { Second } \\
\text { tier }\end{array}$ & $\begin{array}{c}\text { Third } \\
\text { tier }\end{array}$ & Category \\
\hline True & True & Sure & $\begin{array}{c}\text { Know the } \\
\text { Concept(TK) }\end{array}$ \\
\hline True & False & Sure & $\begin{array}{c}\text { Misconceptions 1 } \\
\text { (MK1) }\end{array}$ \\
\hline False & True & Sure & $\begin{array}{c}\text { Misconceptions 2 } \\
\text { (MK 2) }\end{array}$ \\
\hline False & False & Sure & $\begin{array}{c}\text { Misconceptions } \\
\text { (MK 3) }\end{array}$ \\
\hline True & True & $\begin{array}{c}\text { Not } \\
\text { Sure }\end{array}$ & $\begin{array}{c}\text { Do not Know the } \\
\text { Concept (TTK) }\end{array}$ \\
\hline True & False & $\begin{array}{c}\text { Not } \\
\text { Sure }\end{array}$ & $\begin{array}{c}\text { Do not Know the } \\
\text { Concept (TTK) }\end{array}$ \\
\hline False & True & $\begin{array}{c}\text { Not } \\
\text { Sure }\end{array}$ & $\begin{array}{c}\text { Do not Know the } \\
\text { Concept (TTK) }\end{array}$ \\
\hline
\end{tabular}

\begin{tabular}{|c|c|c|c|}
\hline First tier & $\begin{array}{c}\text { Second } \\
\text { tier }\end{array}$ & $\begin{array}{c}\text { Third } \\
\text { tier }\end{array}$ & Category \\
\hline False & False & $\begin{array}{c}\text { Not } \\
\text { Sure }\end{array}$ & $\begin{array}{c}\text { Do not Know the } \\
\text { Concept (TTK) }\end{array}$ \\
\hline
\end{tabular}

Analysis of the result of the misconception shift is used to know the ability of anti-miskim software in reducing misconception on chemical bonding material. This analysis includes analysis of answers per question, the resulting output is the percentage of student concept shifts. Student concept shift is calculated from misconception (MK) to know concept (TK).

Calculations are done through the Excel program with formula below:

$\%$ MR ehfft $=\frac{\Sigma \mathrm{MK}-\mathrm{I}}{\mathrm{MMK} \text { start }} \times 100 \%$

Keterangan :

$\Sigma$ MK-T : the number of misconceptions shifts into concepts

$\Sigma$ MK start : number of students' initial misconceptions

\section{RESULT OF RESEARCH AND DISCUSSION}

Anti Miskim software is tested on the students of class XI MIA 6 SMAN 1 Krembung. The number of students who tested the use of as many as 15 students. The output of the software will be described as follows:

\section{A. Feasibility Analysis Based on Data Validation}

\section{Content Validity}

Criteria of content validity in software developed include: truth of material in software, suitability of material in software with curriculum, material suitability with software with Basic Competence (KD), conformity of material in software with indicator and test purpose.

In the first aspect aims to find out the truth of the material in the software, each item obtains a validity value of 0.75 which is included in the high criterion, so that aspect can be said to be valid.

In the second aspect aims to determine the fulfillment of requirements as software learning to reduce misconception, each item obtains a validity value of 0.75 which is included in the high criterion, so that aspect can be said to be valid.

2. Construct Validation

Criteria of construct validity on software developed include: feasibility in terms of visual appearance, ease of use, practicality as a tool to reduce misconceptions.

In the first aspect relating to the software display, the $1 \mathrm{st}, 3 \mathrm{rd}$, and 4 th items obtain a validity value of 0.75 which is included in the high criterion, while the 2 nd item obtains a validity value of 0.875 which belongs to very high criterion, so that aspect can be said to be valid.

In the second aspect related to ease of use of software, each item obtains a validity value of 0.875 which is included in very high criteria, so that aspect can be said to be valid.

In the third aspect related to the practicality of the software to reduce misconceptions, each item obtains 
a validity value of 0.75 which is included in very high criteria, so that aspect can be said to be valid.

\section{B. Analysis Of Student Responses}

The average percentage of student response results obtained is $89 \%$. The graph of the percentage of student response results obtained are as follows:

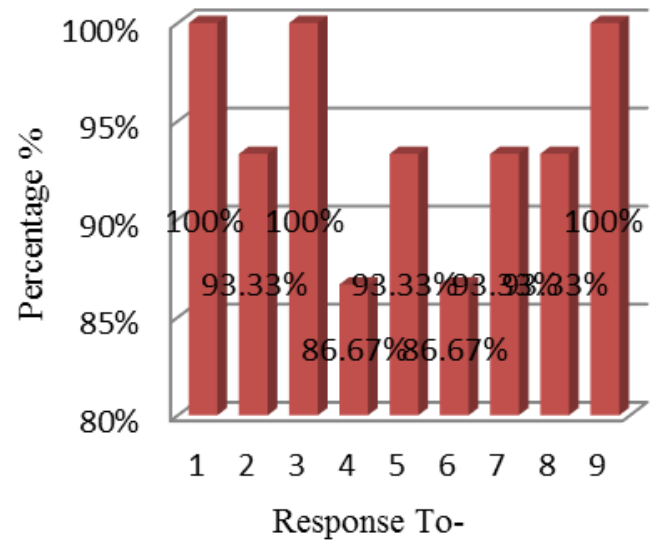

Fig. 2. Graph of Percentage of Student Response Results

In the first response (related to students' understanding of the steps of using Anti Miskim software) and secondly (related to student interest in Anti Miskim software) the results obtained from the student response questionnaire for each response were $100 \%$ and $93.33 \%$.

In the third response (related to the clarity of using Anti Miskim software), the fourth (related to the language used in the software), the fifth (related to ease in understanding chemical bonding problems) and sixth (related to ease in understanding chemical bonding material) the percentages for each response are $100 \%, 86.67 \%, 93.33 \%$, and $86.67 \%$.

In the seventh response (related to the students' interest in chemistry learning using Anti Miskim software), the eighth (related to student spirit in chemistry learning using Anti Miskim software) and the ninth (related to student's independence in studying chemical bonding material using Anti Miskim software) participated in obtaining students response for each response of $93.33 \%, 93.33 \%$, and $100 \%$.

\section{Initial Conception Analysis of Students}

Here is shown the output shift of conception owned by one of the students who have been testing the use of Anti Miskim software

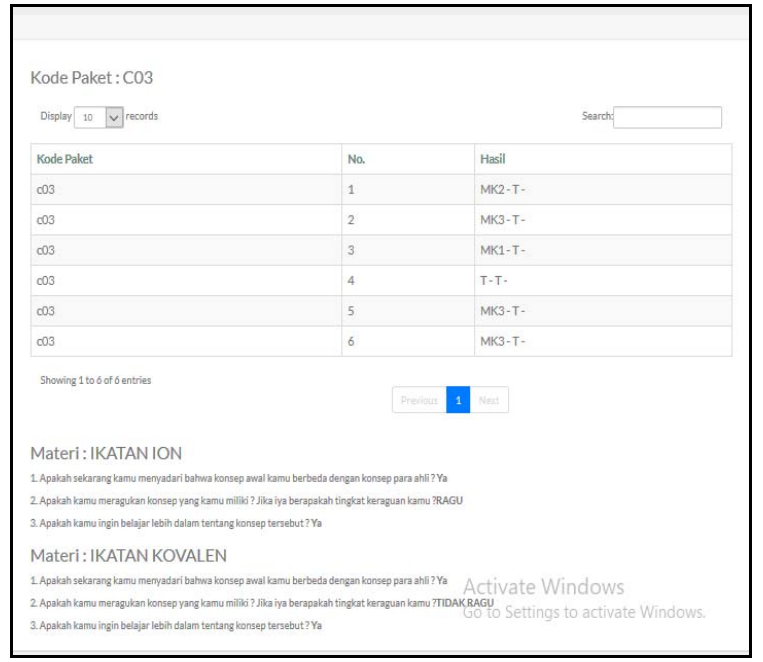

Fig. 3. Display Output Shifting Misconception on AntiMiskim Software

The number of students experiencing misconceptions, know concepts, and do not know the concept is shown by Table 2.

TABLE II. CONCEPTION TEST RESULT ON ION BOND MATERIALS

\begin{tabular}{|c|c|c|c|c|c|c|}
\hline & \multicolumn{2}{|c|}{$\begin{array}{c}\text { Problem } \\
1\end{array}$} & \multicolumn{2}{|c|}{$\begin{array}{c}\text { Problem } \\
2\end{array}$} & \multicolumn{2}{|c|}{$\begin{array}{c}\text { Problem } \\
3 \\
\end{array}$} \\
\hline & 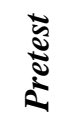 & 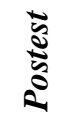 & 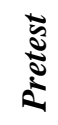 & 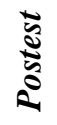 & 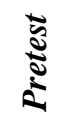 & 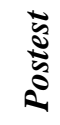 \\
\hline $\begin{array}{c}\text { Number of } \\
T\end{array}$ & 1 & 12 & 3 & 9 & 6 & 12 \\
\hline $\begin{array}{c}\text { Number of } \\
\text { MK1 }\end{array}$ & 6 & 2 & 2 & 1 & 5 & - \\
\hline $\begin{array}{c}\text { Number of } \\
\text { MK2 }\end{array}$ & 3 & - & 1 & - & 1 & - \\
\hline $\begin{array}{c}\text { Number of } \\
\text { MK3 }\end{array}$ & 2 & - & 8 & - & 1 & - \\
\hline $\begin{array}{c}\text { Number of } \\
\text { TK }\end{array}$ & 3 & 1 & 1 & 5 & 2 & 3 \\
\hline
\end{tabular}

Percentage of students experiencing MK1 in ion bond concept is $28.89 \%$, MK2 is $11.11 \%$, and MK3 is $24.44 \%$. While the percentage for students who know the concept $(\mathrm{T})$ is $0.22 \%$.

As for the pretest results of covalent bonds are shown in Table 3

TABLE III. CONCEPTION TEST RESULTS ON COVALENT BOND MATERIALS

\begin{tabular}{|c|c|c|c|c|c|c|}
\hline & \multicolumn{2}{|c|}{ Problem 1} & \multicolumn{2}{|c|}{$\begin{array}{c}\text { Problem } \\
2\end{array}$} & \multicolumn{2}{|c|}{$\begin{array}{c}\text { Problem } \\
3\end{array}$} \\
\hline & 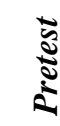 & $\begin{array}{l}\overline{\tilde{O}} \\
\tilde{\Xi} \\
2\end{array}$ & $\begin{array}{l}\bar{\vdots} \\
\bar{\Xi} \\
\overline{\mathbf{s}}\end{array}$ & 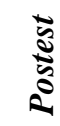 & $\begin{array}{l}\overline{\mathscr{J}} \\
\bar{\Xi}\end{array}$ & $\begin{array}{l}\bar{S} \\
\stackrel{0}{0} \\
0\end{array}$ \\
\hline$\underset{T}{\text { Number of }}$ & 3 & 12 & 2 & 12 & 6 & 11 \\
\hline
\end{tabular}




\begin{tabular}{|c|c|c|c|c|c|c|}
\hline & \multicolumn{2}{|c|}{ Problem 1} & \multicolumn{2}{|c|}{$\begin{array}{c}\text { Problem } \\
2\end{array}$} & \multicolumn{2}{|c|}{$\begin{array}{c}\text { Problem } \\
3 \\
\end{array}$} \\
\hline & 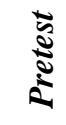 & 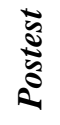 & 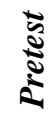 & 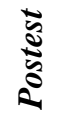 & 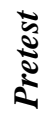 & 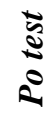 \\
\hline $\begin{array}{c}\text { Number of } \\
\text { MK1 }\end{array}$ & 2 & - & 2 & 1 & 3 & 1 \\
\hline $\begin{array}{c}\text { Number of } \\
\text { MK2 }\end{array}$ & 5 & - & 1 & - & 2 & - \\
\hline $\begin{array}{c}\text { Number of } \\
\text { MK3 }\end{array}$ & 4 & - & 6 & - & 2 & - \\
\hline $\begin{array}{c}\text { Number of } \\
\text { TK }\end{array}$ & 1 & 3 & 4 & 2 & 2 & 3 \\
\hline
\end{tabular}

Percentage of students experiencing MK1 in ion bond concept is $15.56 \%$, MK2 is $17.78 \%$, and MK3 is $26.67 \%$. While the percentage for students who know the concept is $24.44 \%$.

\section{Analysis of The Results of Answers Per Problem}

\section{Concept of Ionic Bonds}

The first pretest problem on the concept of ionic bonds is the definition of ionic bonds. In this problem found students who experienced miskonsepsi MK1 as many as 6 students, MK2 as many as 3 students, and MK3 as many as 2 students. After reading the conceptual change text (CCT) which has been presented in Anti Miskim software there is a change of conception on the students. The percentage of conception shifts from misconceptions (both MK1, MK2, and MK3) to know concept (T) for the first pretest problem of ionic bonds is $81.82 \%$.

The second pretest problem of ionic bonds is related to the physical properties of ionic compounds. Students who experienced MK3 for the second problem were 8 students from 15 students. After reading the conceptual change text (CCT) which has been presented in Anti Miskim software there is a change of conception on the students. The percentage of conception shifts from misconceptions (both MK1, MK2, and MK3) to know the concept (T) for the pretest problem of both ionic bonds is $72.73 \%$.

The third pretest problem of ionic bonds is related to the example of the ionic compound. Students who experienced MK1 for the second problem as many as 7 students from 15 students. After reading the conceptual change text (CCT) which has been presented in Anti Miskim software there is a change of conception on the students. The percentage of conception shifts from misconceptions (both MK1, MK2, and MK3) to know the concept (T) for the first pretest of ionic bonds is $85.71 \%$.

2. Concept of Covalent Bonds

The first pretest problem of covalent bonds about definition of covalent bonds found that the number of students with misconceptions of either MK1, MK2, or MK3 was 11 out of 15 students. After reading the conceptual change text (CCT) which has been presented in Anti Miskim software there is a change of conception on the students. The percentage of conception shifts from misconceptions (both MK1, MK2, and MK3) to know the concept (T) for the first pretest problem of ionic bonds is $81.82 \%$.

The second pretest problem of covalent bonds is related to the process of formation of covalent bonds. The number of students who experienced misconception either MK1, MK2, or MK3 was as many as 9 out of 15 students. After reading the conceptual change text (CCT) which has been presented in Anti Miskim software there is a change of conception on the students. The shift in the conception of misconceptions (both MK1, MK2, and MK3) becomes aware of the concept (T) for the pretest of both ionic bonds of $72.73 \%$.

The third pretest issue of covalent bonding is concerned with the physical properties of covalent compounds. The number of students experiencing misconceptions of either MK1, MK2, or MK3 is 7 out of 15 students. The percentage of conception shifts from misconceptions (both MK1, MK2, and MK3) to know the concept (T) for the first pretest of ionic bonds is $85.71 \%$.

\section{CONCLUSION}

Based on the results of data analysis can be concluded that Anti Miskim software can reduce misconception in chemical bond material effectively based on data validation result by chemistry lecturer, positive response from student, and student conception shift. The description of the conclusion is as follows:

A. Anti Miskim software validity on chemical bonding material based on the validation result done by the chemistry lecturer obtained the average validation result of 0.775 . So the software is said to be valid for use.

$B$. The practicality of Anti Miskim software on chemical bond material based on student response result supported by data observation result of student activity get average result equal to $94.07 \%$.

C. Anti Miskim software can be said to be effective in reducing student misconceptions. This is evidenced by the average percentage of MK-T concept shift (misconception to know the concept) is equal to $81.26 \%$.

\section{ACKNOWLEDGMENT}

The author is very grateful to the Dean as the head of the Faculty of Mathematics and Natural Sciences which has facilitated the completion of this manuscrip.

\section{REFERENCES}

[1] Kean, E \& Middlecamp, C., Basic Chemistry Guide (Panduan Belajar Kimia Dasar), Jakarta : Gramedia, 1985.

[2] Kolb, D., Experiential Learning: Experience as the Source of Learning and Development, Prentice-Hall: Englewood Cliffs, 1984.

[3] Rahman, N. A., Secondary Physics Teachers, Attitudes, Strategies And Reflections On Practice In Relation To Pupils' Misconceptions. The University of Mancester, 2004.

[4] Hewson, Conceptual Change Text in Science Teaching and Teacher Education, Madrid : National Center for Education, 1992. 
[5] Davis, J., Conceptual Change. In M. Orey (Ed.), Emerging perspectives on learning, teaching, and technology, (Online), http://epltt.coe.uga.edu/index.php?title=Conceptual_Change, accessed on date 22 November 2017, 2001.

[6] Syuhendri, "Conceptual Change Learning Student : Essay Writing Choices (Pembelajaran Perubahan Konseptual: Pilihan Penulisan Skripsi Mahasiswa)". Forum Mipa, 2010, vol. 13 (2): pp. 133- 140

[7] Nuha, Wilda Ulin, dan Sukarmin, "Development of Chemical Misconception Detection Software (Pengembangan Software Pendeteksi Miskonsepsi Kimia)", Unesa Journal of Chemical Education, 2013, vol. 2 (3), pp. 85-89.

[8] Suprianto dan Sukarmin, Software Development to Measure The Level Of Cognitive Conflict In Acid-Base Material In Class XI-IPA 6 SMAN 1 Driyorejo Gresik (Pengembangan Software untuk Mengukur Tingkat Konflik Kognitif pada Materi Asam Basa di Kelas XI IPA 6 SMAN 1 Driyorejo Gresik), Written as essay in Surabaya State University, 2016.

[9] Sugiyono, Quantitative, Qualitative and R\&D Research Methods (Metode Penelitian Kuantitatif, Kulatitatif dan R\&D). Bandung: Alfa Beta, 2017.

[10] Arslan, H. Ozge, Cigdemoglu, Ceyhan \& Moseley Christine, "ThreeTier Diagnostic Test to Assess Pre-Service Teachers' Misconceptions about Global Warming, Greenhouse Effect, Ozoner Layer Depletion, and Acid Rain". International Journal of Science Education, 2012, Vol. 34 (11), pp. 1667-1686. 